\title{
Comparative Photocatalytic Degradation of Monoazo and Diazo Dyes Under Simulated Visible Light Using $\mathrm{Fe}^{3+} / \mathrm{C} / \mathrm{S}$ doped-TiO 2 Nanoparticles
}

\section{William Wilson Anku,* Samuel Osei-Bonsu Oppong, Sudheesh Kumar Shukla and Poomani Penny Govender*}

\author{
Department of Applied Chemistry, University of Johannesburg, P.O. Box 17011, Doornfontein 2028, \\ Johannesburg, South Africa. \\ * Corresponding author: E-mail: pennyg@uj.ac.za, williamanku85@ gamil.com
}

Tel: +275596555

Received: 26-02-2016

\begin{abstract}
This research work delved into the photocatalytic degradation of monoazo dye (methyl orange) and diazo dye (congo red) in aqueous solution using $\mathrm{Fe}^{3+} / \mathrm{C} / \mathrm{S}$-doped $\mathrm{TiO}_{2}$ nanocomposites. The nanocomposites were synthesised through sol-gel method and characterized using XRD, FTIR, SEM, TEM, EDX, BET and UV-Vis. Photocatalytic degradation of the dyes was monitored under simulated visible light using pristine $\mathrm{TiO}_{2}, \mathrm{C} / \mathrm{S} /$ doped- $\mathrm{TiO}_{2}$ and $\mathrm{Fe}^{3+} / \mathrm{C}_{\mathrm{S}} \mathrm{doped}-\mathrm{TiO}{ }_{2}$ with varying concentrations of $\mathrm{Fe}^{3+}$. The influence of catalyst doping, solution $\mathrm{pH}$, and light intensity were also examined. Doping $\mathrm{TiO}_{2}$ with $\mathrm{Fe}^{3+} / \mathrm{C} / \mathrm{S}$ caused reduction in its band gap value with the resultant improvement in its visible light activity. The photocatalytic efficiency of the catalysts is given as follows: $\mathrm{TiO}_{2}<\mathrm{C} / \mathrm{S} / \mathrm{TiO}_{2}<\mathrm{Fe}^{3+} / \mathrm{C} / \mathrm{S}-\mathrm{TiO}_{2}$ with $\mathrm{Fe}^{3+} / \mathrm{C} / \mathrm{S}-\mathrm{TiO}_{2}\left(0.3 \% \mathrm{Fe}^{3+}\right)$ as the best performing photocatalyst. The monoazo dye experienced higher degradation efficiency than the diazo dye. Degradation of the azo dyes was observed to decrease with increasing $\mathrm{pH}$ from 2 to 12 . Increased visible light intensity enhanced the photodegradation efficiency of the dye. Dye decolourization was observed to be faster than its mineralization.
\end{abstract}

Keywords: $\mathrm{TiO}_{2}$, metals, non-metals, azo dyes, photocatalytic degradation, sol-gel method.

\section{Introduction}

The release of dye polluted wastewater by textile industries into surface water is causing serious environmental challenges. These challenges are not only limited to the aesthetic impact on the water bodies, the negative effect on aquatic plants and death of fish but also the health effects posed to humans, as many of these dyes are toxic and carcinogenic. ${ }^{1,2}$

A large number of dyes with varied chemical structures are used in the textile industries for dyeing purposes. Based on their chemical structures in terms of chromophore groups, dyes can be classified as azo dyes, anthraquinone dyes, and reactive dyes and so on. Azo dyes are the most abundant group of dyes used in the textile industries. The main characteristics of these dyes are the presence of one or more azo $(\mathrm{N}=\mathrm{N})$ bonds and bonds between aromatic rings. ${ }^{3,4}$ Certain characteristics of dyes such as toxicity, resistance to degradation and photodegradation rates are believed to be dependent on the chemical structure of each dye. ${ }^{4,5}$ For example, Giwa et al, ${ }^{6}$ investigated the photodegradation of Reactive Yellow 81 and Reactive Violet 1 in aqueous solution with $\mathrm{TiO}_{2}-\mathrm{P} 25$ (Degussa) and observed that structural variation between the dyes molecules may have influenced their degradation rates. With regards to aromatic compounds, the number, position and the electronic nature of the substituents determine the efficiency of the photocatalytic degradation process. ${ }^{7}$ In their studies to determine the structural effect on photocatalytic degradation of substituted phenols through the use of $\mathrm{TiO}_{2}$ nanoparticles, Parra et al, ${ }^{8}$ observed that photoreactivity of substituted phenol depend on the electronic nature of the substitutes and their positions in the aromatic ring. The photocatalytic degradation process is more effective with greater electronic density on the aromatic ring. ${ }^{8}$ Therefore, it necessary to design technologies capable of photode- 
grading these dyes with their structural differences in mind.

There has recently been considerable interest in the use of semiconductor photocatalysts for degradation of dyes in wastewater. There has been several reports on the use of $\mathrm{TiO}_{2}$ to degrade organic compounds in wastewater, ${ }^{9,10}$ due to its numerous advantages including high optical, electronic and photocatalytic properties, chemical stability, non-toxicity and low cost. ${ }^{11}$ In spite of these advantages, the practical application of $\mathrm{TiO}_{2}$ as an efficient photocatalyst for complete photodegradation of organic pollutants in wastewater is hampered by some inherent problems associated with $\mathrm{TiO}_{2}$ as a photocatalyst. These problems include its relatively high band gap of $3.2 \mathrm{eV}$ which limits its ability to work in the visible light range, and its sensitivity to recombination of photogenerated electrons and hole, which decrease its photocatalytic activity. ${ }^{12}$

In order to enhance the photocatalytic activity of $\mathrm{TiO}_{2}$, its band gap must be reduced, and the recombination rate of the photogenerated electrons and holes minimized. Lots ofeffort has been made into achieving these goals through various modification techniques. One common and most effective method to minimize the electron-hole recombination rate, and extend the absorption edge of $\mathrm{TiO}_{2}$ from the ultraviolet to visible light region is by doping $\mathrm{TiO}_{2}$ with transition metal cations. ${ }^{13,14}$ Out of many transition metals, iron has been regarded as a suitable dopant. $\mathrm{Fe}^{3+}$ has a radius of $0.69 \mathrm{~A}$ which is very similar to that of $\mathrm{Ti}^{4+}(0.75$ A). This makes it easier for $\mathrm{Fe}^{3+}$ to be easily incorporated into $\mathrm{TiO}_{2}$ lattice. Furthermore, $\mathrm{Fe}^{3+}$ has the potential for trapping photogenerated electrons and holes since the energy level of $\mathrm{Fe}^{2+} / \mathrm{Fe}^{3+}$ lies close to that of $\mathrm{Ti}^{3+} / \mathrm{Ti}^{4+}$. ${ }^{15}$ This subsequently results in improved separation of electron-hole pairs leading to improvement in quantum yield. ${ }^{16}$

Extensive studies have also been undertaken to improve the efficiency of $\mathrm{TiO}_{2}$ as a photocatalyst through the use of nonmetal dopants such as nitrogen, ${ }^{17}$ carbon, ${ }^{18}$ sulphur ${ }^{19}$ and fluorine. ${ }^{20}$ Band gap narrowing has been reported in $\mathrm{C}, \mathrm{S}$, and $\mathrm{N}$ doped $\mathrm{TiO}_{2}{ }_{2}^{21,22}$ with $\mathrm{C}$-doped $\mathrm{TiO}_{2}$ exhibiting the best band gap narrowing ability. ${ }^{23}$ When doped together in $\mathrm{TiO}_{2}$, the combined effect of charge separation ability of $\mathrm{Fe}^{3+}$ and band gap narrowing potential of $\mathrm{C}$ and $\mathrm{S}$ is envisaged to result in modified $\mathrm{TiO}_{2}$ with excellent optical and photocatalytic properties.
This work therefore involved the synthesis of pristine $\mathrm{TiO}_{2}, \mathrm{C} / \mathrm{S}$-doped $\mathrm{TiO}_{2}$ and $\mathrm{Fe}^{3+} / \mathrm{C} / \mathrm{S}$-doped $\mathrm{TiO}_{2}$ with varying weight percent of $\mathrm{Fe}^{3+}(0.3 \%, 0.6 \%$ and $1.0 \%)$ through the sol-gel method of preparation. The photocatalytic degradation potential of these catalysts was assessed by their degradation of a monoazo dye (methyl orange) and diazo dye (congo red) as a function of time in aqueous solution under simulated visible light. The degradation of these two dyes by the catalysts were compared with regards to their structural differences. The influence of factors such as catalyst modification, $\mathrm{pH}$ and visible light intensity on the photocatalytic degradation of the dyes, as well as the degree of mineralization of the dyes was also studied using the catalyst with the best photodegradation potential.

\section{Experimental}

\section{1. Chemicals and Reagents}

Thiourea $\left(\mathrm{CS}\left(\mathrm{NH}_{2}\right)_{2}\right)$, 99\% was procured from Hopkin and Williams Ltd., England. Iron (III) chloride hexahydrate $\left(\mathrm{FeCl}_{3} \cdot 6 \mathrm{H}_{2} \mathrm{O}\right), 99 \%$ was purchased from Merck, South Africa.The two azo dyes, Congo red and Methyl orange, absolute ethanol and titanium (IV) isopropoxideTi $\left(\mathrm{OC}_{3} \mathrm{H}_{7}\right)_{4}, 97 \%$ were purchased from Sigma Aldrich, Germany.All chemicals used in this work were of analytical grade and were used without any further purification. Double distilled water was used throughout the experiment. The dye standard solutions were prepared by dissolving the appropriate masses of both congo red and methyl orange in $1000 \mathrm{~mL}$. The standard solutions were then diluted to obtain the desired $20 \mathrm{ppm}$ solution of each dye. The structures of the two azo dyes are shown in Figure 1 .

\section{2. Synthesis of $\mathrm{Fe}^{3+} / \mathrm{C} / \mathrm{S}$-doped $\mathrm{TiO}_{2}$}

Titanium (IV) isopropoxide $(12.5 \mathrm{~mL})$ was added to $50 \mathrm{~mL}$ absolute ethanol, followed by the dropwise addition of $1 \mathrm{~mL}$ polyethylene glycol. The mixture was stirred for $30 \mathrm{~min}$. Calculated amounts of iron (III) chloride hexahydrate representing $\mathrm{Ti}$ : Fe ratios of $0.3 \%, 0.6 \%$ and $1.0 \%$ were dissolved in $2 \mathrm{~mL}$ deionized water and added to the mixture. The mixture was stirred for another $1 \mathrm{~h}$.

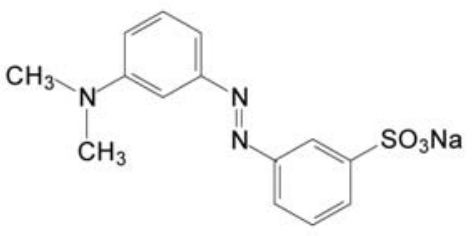

Methyl orange

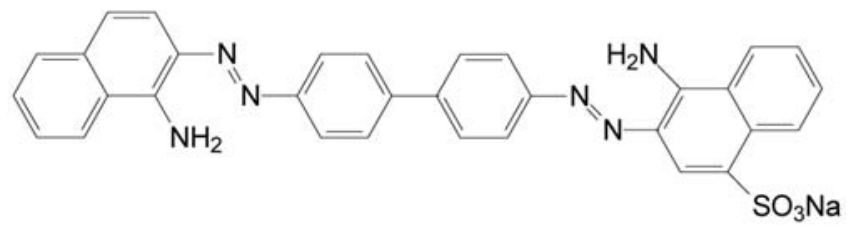

Congo red

Figure 1. Structure of methyl orange and congo red 
Thereafter, 3. $0 \mathrm{~g}$ of thiourea, which served as the source of $\mathrm{C}$ and $\mathrm{S}$, was dissolved in $10 \mathrm{~mL}$ deionized water and added to the mixture slowly with further stirring for another $2 \mathrm{~h}$. Finally, the mixture was dried in an oven at $100{ }^{\circ} \mathrm{C}$ for $12 \mathrm{~h}$ and calcined at $500{ }^{\circ} \mathrm{C}$ for $3 \mathrm{~h}$. The pristine $\mathrm{TiO}_{2}$ and $\mathrm{C} / \mathrm{S}-\mathrm{TiO}_{2}$ were also synthesized following the same procedure but without the addition of both iron (III) chloride hexahydrate and thiourea (in the case of $\mathrm{TiO}_{2}$ ), and iron (III) chloride hexahydrate (for $\mathrm{C} / \mathrm{S}-\mathrm{TiO}_{2}$ ).

\section{3. Characterizations}

The X-ray diffraction (XRD) pattern was recorded on Philips PANalytical X'pert PRO X-ray diffractometer operating at $40 \mathrm{kV}$ using $\mathrm{Cu}-\mathrm{K} \alpha$ radiation $(\lambda=0.1541 \mathrm{~nm})$. The measurement was performed over a diffraction angle range of $2 \theta=10^{\circ}-100^{\circ}$. Fourier transform infrared (FTIR) spectroscopy for the nanocomposites was recorded on PerkinElmer spectrometer (Spectrum 100) in the wavelength range of 400 to $4000 \mathrm{~cm}^{-1}$. The FTIR study was performed by using potassium bromide (KBr) pellet. Scanning electron microscopy (SEM) images were taken with a TESCAN (Vega $3 \mathrm{XMU}$ ) instrument. The elemental composition was studied using energy dispersed $\mathrm{x}$-ray (EDX) attached to SEM. Transmission electron microscopy (TEM) images were taken using the TEM microscope (JEOL, JEM-2100F) with a working voltage of $120 \mathrm{kV}$. Investigation of the optical absorption properties was carried out using a UV-Vis spectrophotometer (Shimadzu UV-2450). Barium sulphate $\left(\mathrm{BaSO}_{4}\right)$ was used as the reflectance standard.

\section{4. Photodegradation Studies of the dye Solutions}

The photocatalytic degradation ability of the as synthesized nanoparticles on the two dye solutions was determined by measuring the absorbance of the dye solutions before and after their photodegradation, and the determination of the total organic carbon (TOC) of the dyes solutions before and after their degradation. The simulated visible light intensity was varied using Oriel PV reference cell system model $9115 \mathrm{~V}$ to produce a beam power equivalent to 0.5 sun, 0.7 sun, 1.0 sun and 1.3 sun intensities. This was achieved by setting the distance between the solar simulator (equipped with $150 \mathrm{~W}$ ozone free xenon lamp) and the experimental set up to distances of $15 \mathrm{~cm}$, $13 \mathrm{~cm}, 10 \mathrm{~cm}$ and $0.7 \mathrm{~cm}$ respectively. The pHs of the solutions were varied by adding $2 \mathrm{M} \mathrm{HCl}$ and $2 \mathrm{M} \mathrm{NaOH}$ solutions and monitored using Orion Per Hect $\mathrm{pH}$ meter. A Teledyne Tekmar TOC fusion meter, USA, was used for the total organic carbon analysis.

\section{5. Evaluation of Photocatalytic Activity}

The photocatalytic activities of the as-synthesized pristine $\mathrm{TiO}_{2}, \mathrm{C} / \mathrm{S}-\mathrm{TiO}_{2}$ and $\mathrm{Fe}^{3+} / \mathrm{C} / \mathrm{S}-\mathrm{TiO}_{2}$ were probed by their application in the degradation of $20 \mathrm{ppm}$ aqueous solutions of methyl orange and congo red under simulated visible light. In this experiment, $20 \mathrm{~mL}$ (20 ppm) solution of each dye was placed in seven $50 \mathrm{~mL}$ beakers labelled $0-6$. The photocatalysts $(0.02 \mathrm{~g})$ were mixed with each of the 7 dye solutions and the mixtures stirred magnetically in the dark for $30 \mathrm{~min}$ to establish adsorption equilibrium between the dyes and the catalysts. As a control, the beakers labelled zero (0) were removed after the 30 min stirring without visible light illumination. Then, $5 \mathrm{~mL}$ aliquot of this solution was withdrawn using disposable syringes fitted with $0.45 \mu \mathrm{m}$ PVDF membranes. The remaining solutions labelled 1-6 were then illuminated using a Newport solar simulator, port 9600 full spectrum equipped with 150W ozone free xenon lamp, and fitted with a dichroic UV filter with a wavelength of $420 \mathrm{~nm}$. The illumination was carried out for $180 \mathrm{~min}$. The visible light illuminated solutions were chronologically removed from 1-6 after every $30 \mathrm{~min}$ interval and $5 \mathrm{~mL}$ aliquot of each was taken. The degradation was performed at the solution $\mathrm{pH}$ and 1 sun intensity. The concentrations of the dyes in the withdrawn solution after illumination $(5 \mathrm{~mL})$ were determined using Shimadzu UV-2450 spectrophotometer at wavelengths of $497 \mathrm{~nm}$ and $462 \mathrm{~nm}$ for congo red and methyl orange respectively. The same procedure was followed for the degradation experiments at pHs 3, 7, 9 and 12, and visible light intensities of 0.7 sun, 1.0 sun and 1.3 sun.

\section{Results and Discussions}

\section{1. FTIR Analysis}

The FTIR spectra of the as-synthesized undoped Ti$\mathrm{O}_{2}$, C/S-doped $\mathrm{TiO}_{2}$ and $\mathrm{Fe}^{3+} / \mathrm{C} / \mathrm{S}$-doped $\mathrm{TiO}_{2}$ with varying contents of $\mathrm{Fe}^{3+}$ are presented in Figure 2. In all the spectra, the strong and broad band below $1000 \mathrm{~cm}^{-1}$ is assigned to the combined bands of $\mathrm{Ti}-\mathrm{O}-\mathrm{Ti}, \mathrm{Fe}-\mathrm{O}-\mathrm{Ti}$, $\mathrm{S}-\mathrm{O}-\mathrm{Ti}$ and $\mathrm{O}-\mathrm{Ti}-\mathrm{C}$ crystal vibrations, ${ }^{24}$ and the absorption bands at $1628 \mathrm{~cm}^{-1}$ and around $3500 \mathrm{~cm}^{-1}$ are due to $-\mathrm{OH}$ bending and stretching vibrations respectively as a result of absorbed water molecules. For the $\mathrm{C} / \mathrm{S}$-doped Ti$\mathrm{O}_{2}$ and $\mathrm{Fe}^{3+} / \mathrm{C} / \mathrm{S}$-doped $\mathrm{TiO}_{2}$ photocatalysts (Figure $2 \mathrm{~b}, 2 \mathrm{c}$, $2 \mathrm{~d}$ and $2 \mathrm{e}$ ), the peak located at $1065 \mathrm{~cm}^{-1}$ may be attributed to bidentate sulphate ions $\left(\mathrm{SO}_{4}{ }^{2-}\right)$ co-ordinated to metal ions such as $\mathrm{T}^{4+} \cdot{ }^{25} \mathrm{In}$ addition, the peak at $1130 \mathrm{~cm}^{-1}$ can be ascribed to the $\mathrm{S}=\mathrm{O}$ stretching vibration. ${ }^{26}$ The small peak at $2048 \mathrm{~cm}^{-1}$ may be a consequence of an outof-phase stretching band of $-\mathrm{N}=\mathrm{C}=\mathrm{O} .^{27}$ The spectra for $\mathrm{Fe}^{3+} / \mathrm{C} / \mathrm{S}$-doped $\mathrm{TiO}_{2}$ (with varying $\mathrm{Fe}$ content) is similar to that of $\mathrm{C} / \mathrm{S}$-doped $\mathrm{TiO}_{2}$ but with changes in relative intensities and peak positions with increasing $\mathrm{Fe}$ content. The intensities of the absorption bands for $\mathrm{Fe}^{3+} / \mathrm{C} / \mathrm{S}-\mathrm{do}-$ ped $\mathrm{TiO}_{2}\left(0.3 \% \mathrm{Fe}^{3+}\right)$, (Figure $2 \mathrm{c}$ ), are comparatively higher than those of the other nanocomposites. This observation is a possible confirmation that the $\mathrm{Ti}^{4+}$ is perfectly substituted by $\mathrm{Fe}^{3+}$ at this concentration. 


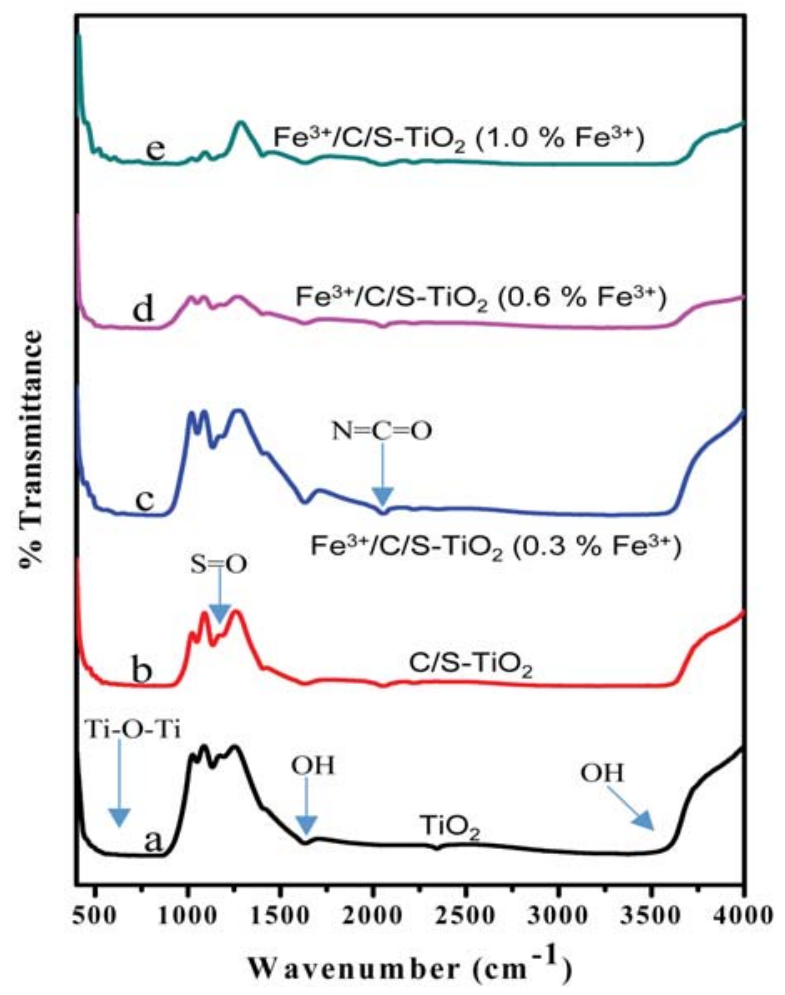

Figure 2. FT-IR spectra of pristine $\mathrm{TiO}_{2}, \mathrm{C} / \mathrm{S}-\mathrm{TiO}_{2}$ and $\mathrm{Fe}^{3+} / \mathrm{C} / \mathrm{S}-$ doped $\mathrm{TiO}_{2}$ with varying concentrations of $\mathrm{Fe}^{3+}$.

\section{2. Powder XRD Analysis}

The powder X-Ray diffraction patterns of undoped $\mathrm{TiO}_{2}, \mathrm{C} / \mathrm{S}$-doped $\mathrm{TiO}_{2}$ and $\mathrm{Fe}^{3+} / \mathrm{C} / \mathrm{S}$-doped $\mathrm{TiO}_{2}$ are shown in Figure 3. All the diffractions are peaks characteristic of Anatase crystalline phase of $\mathrm{TiO}_{2}$. These peaks occur at $2 \theta$ values of $25.3^{\circ}, 37.9^{\circ}, 48.1^{\circ}, 53.9^{\circ}, 55.0^{\circ}$, $62.9^{\circ}, 68.9^{\circ}, 70.4^{\circ}, 75.8^{\circ}$ and correspond to diffraction planes of 101, 004, 200, 105, 211, 204, 116, 200 and 215 respectively. This diffraction pattern is comparable to JCPDS no_ 21-1272. No Fe containing crystalline phase was observed in the XRD pattern. For a coordinated number of $6, \mathrm{Fe}^{3+}$ and $\mathrm{Ti}^{4+}$ have similar ionic radii of $0.65 \dot{\mathrm{A}}$ and 0.75 Ärespectively. $\mathrm{Fe}^{3+}$ can therefore easily substitute $\mathrm{Ti}^{4+}$ in the $\mathrm{TiO}_{2}$ lattice. ${ }^{28}$ The result of this analysis therefore means that there was a uniform substitution of $\mathrm{Ti}^{4+}$ with $\mathrm{Fe}^{3+}$ dopant. It is also evident that the catalysts are small in size due to the broad nature of the peaks. Crystallite sizes of catalysts were calculated using the DebyeScherrer's equation: ${ }^{29}$

$$
D=\frac{K_{\lambda}}{\beta \cos \theta}
$$

where, $\mathrm{D}$ is the crystallite size, $K$ is a shape factor with a value of $0.9, \lambda$ is the wavelength of the $\mathrm{X}$-ray $(0.1541$ $\mathrm{nm}), \beta$ is the value of full width at half maximum (FWHM) in the radiation of (101) plane in $2 \theta$ scale, and $\theta$ is the Bragg's diffraction angle at the maximum. The crystallite sizes were found to be $23.0 \mathrm{~nm}, 19.4 \mathrm{~nm}, 15.7$ $\mathrm{nm}, 12.3 \mathrm{~nm}$ and $7.2 \mathrm{~nm}$ for $\mathrm{TiO}_{2}, \mathrm{C} / \mathrm{S}$-doped $\mathrm{TiO}_{2}$, $\mathrm{Fe}^{3+} / \mathrm{C} / \mathrm{S}$-doped $\mathrm{TiO}_{2}\left(0.3 \% \mathrm{Fe}^{3+}\right), \mathrm{Fe}^{3+} / \mathrm{C} / \mathrm{S}$-doped $\mathrm{TiO}_{2}$ $\left(0.6 \% \mathrm{Fe}^{3+}\right)$ and $\mathrm{Fe}^{3+} / \mathrm{C} / \mathrm{S}$-doped $\mathrm{TiO}_{2}\left(1.0 \% \mathrm{Fe}^{3+}\right)$ respectively. It is evident that doping led to a decrease in the crystallite size of $\mathrm{TiO}_{2}$ and the size decreased consistently with increasing $\mathrm{Fe}^{3+}$ content. This decreased particle size may result in well-defined nanocrystalline powders with high surface area. ${ }^{30}$

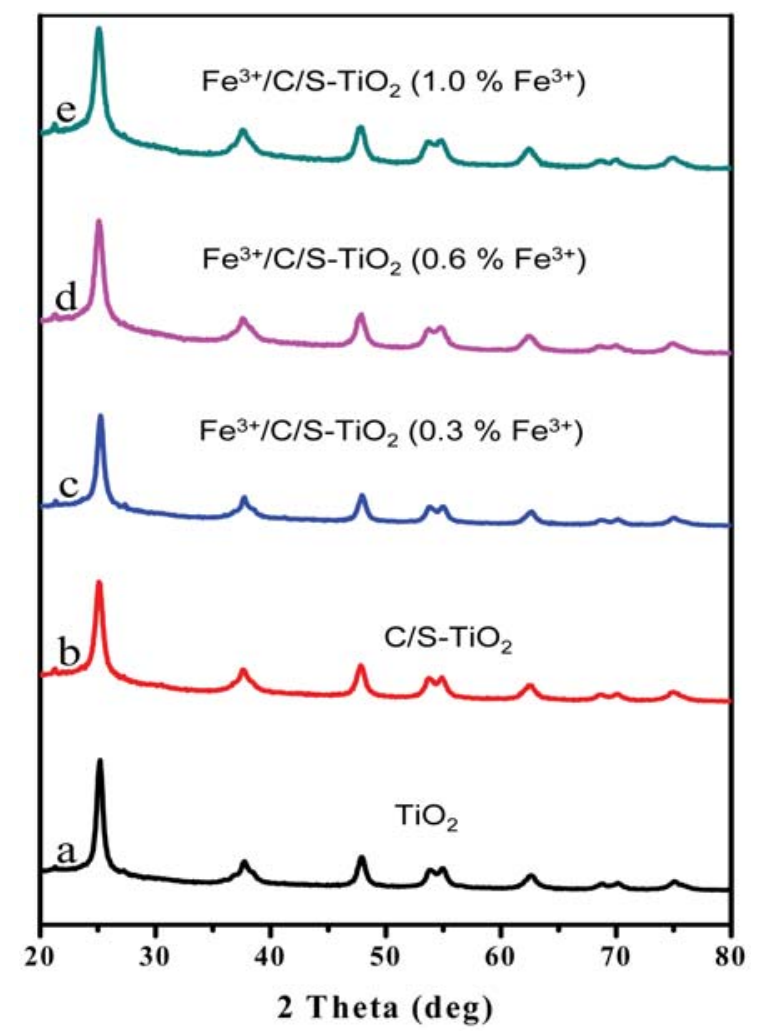

Figure $3 \mathrm{XRD}$ patterns of pristine $\mathrm{TiO}_{2}, \mathrm{C} / \mathrm{S}-\mathrm{TiO}_{2}$ and $\mathrm{Fe}^{3+} / \mathrm{C} / \mathrm{S}-$ doped $\mathrm{TiO}_{2}$ with varying concentrations of $\mathrm{Fe}^{3+}$.

\section{3. Brunauer-Emmett-Teller (BET) Surface Area Analysis}

The surface area analysis was intended to provide specific surface area assessment of the nanoparticles. Nitrogen adsorption-desorption isotherm was used to establish the effect of Fe doping on the BET surface, pore volumes and pore sizes of the nanoparticles. The results of the BET surface area, pore volume, and pore size analysis are presented in Table 1. The result shows that the nanocomposites exhibited increased surface area with decreased crystallite size. Thus the undoped $\mathrm{TiO}_{2}$ had the least surface area of $32.7 \mathrm{~m}^{2} / \mathrm{g}$ while the $\mathrm{Fe}^{3+} / \mathrm{C} / \mathrm{S}$-doped $\mathrm{TiO}_{2}(0.3 \%$ $\mathrm{Fe}^{3+}$ ) had the largest specific surface area of $74.6 \mathrm{~m}^{2} / \mathrm{g}$. Larger surface area can result in improved photocatalytic 
Table 1 Surface area, pore volume, pore size, indirect band gap, and percent degradation based on catalyst doping at solution pH and visible light irradiation with 1 sun intensity

\begin{tabular}{|c|c|c|c|c|c|c|}
\hline \multirow{2}{*}{ Sample } & \multirow{2}{*}{$\begin{array}{c}\text { Surface area } \\
\left(\mathrm{m}^{2} / \mathrm{g}\right)\end{array}$} & \multirow{2}{*}{$\begin{array}{l}\text { Pore volume } \\
\quad\left(\mathrm{cmg}^{-1}\right)\end{array}$} & \multirow{2}{*}{$\begin{array}{l}\text { Pore size } \\
\text { (nm) }\end{array}$} & \multirow{2}{*}{$\begin{array}{l}\text { Indirect band } \\
\text { gap }(e V)\end{array}$} & \multicolumn{2}{|c|}{$\%$ Degradation } \\
\hline & & & & & Methyl Orange & Congo Red \\
\hline$\overline{\mathrm{TiO}_{2}}$ & 32.7 & 0.137 & 3.825 & 3.20 & 32.5 & 15.2 \\
\hline $\mathrm{C} / \mathrm{S}-\mathrm{TiO}_{2}$ & 32.5 & 0.180 & 3.794 & 2.42 & 69.4 & 61.9 \\
\hline $\mathrm{Fe}^{3+} / \mathrm{C} / \mathrm{S}-\mathrm{TiO}_{2}\left(0.3 \% \mathrm{Fe}^{3+}\right)$ & 74.3 & 0.212 & 3.775 & 2.00 & 93.5 & 87.9 \\
\hline $\mathrm{Fe}^{3+} / \mathrm{C} / \mathrm{S}-\mathrm{TiO}_{2}\left(0.6 \% \mathrm{Fe}^{3+}\right)$ & 56.1 & 0.224 & 3.719 & 2.14 & 90.7 & 83.0 \\
\hline $\mathrm{Fe}^{3+} / \mathrm{C} / \mathrm{S}-\mathrm{TiO}_{2}\left(1.0 \% \mathrm{Fe}^{3+}\right)$ & 44.6 & 0.233 & 3.667 & 2.26 & 86.4 & 80.0 \\
\hline
\end{tabular}

property as a result of availability of more active surface sites for improved adsorption of dye molecules. ${ }^{31}$ In addition, the pore volumes increase while the pore sizes decrease with increasing Fe concentration. Thus doping Ti$\mathrm{O}_{2}$ with $\mathrm{Fe}$ ensured nanoparticles with larger surface area and pore volumes, and reduced pore sizes.

\section{4. SEM, TEM and EDX Analysis}

The surface morphology, microstructure and elemental compositions of the as-synthesized nanoparticles were investigated using scanning electron microscopy (SEM), transmission electron microscopy (TEM) and energy dis-

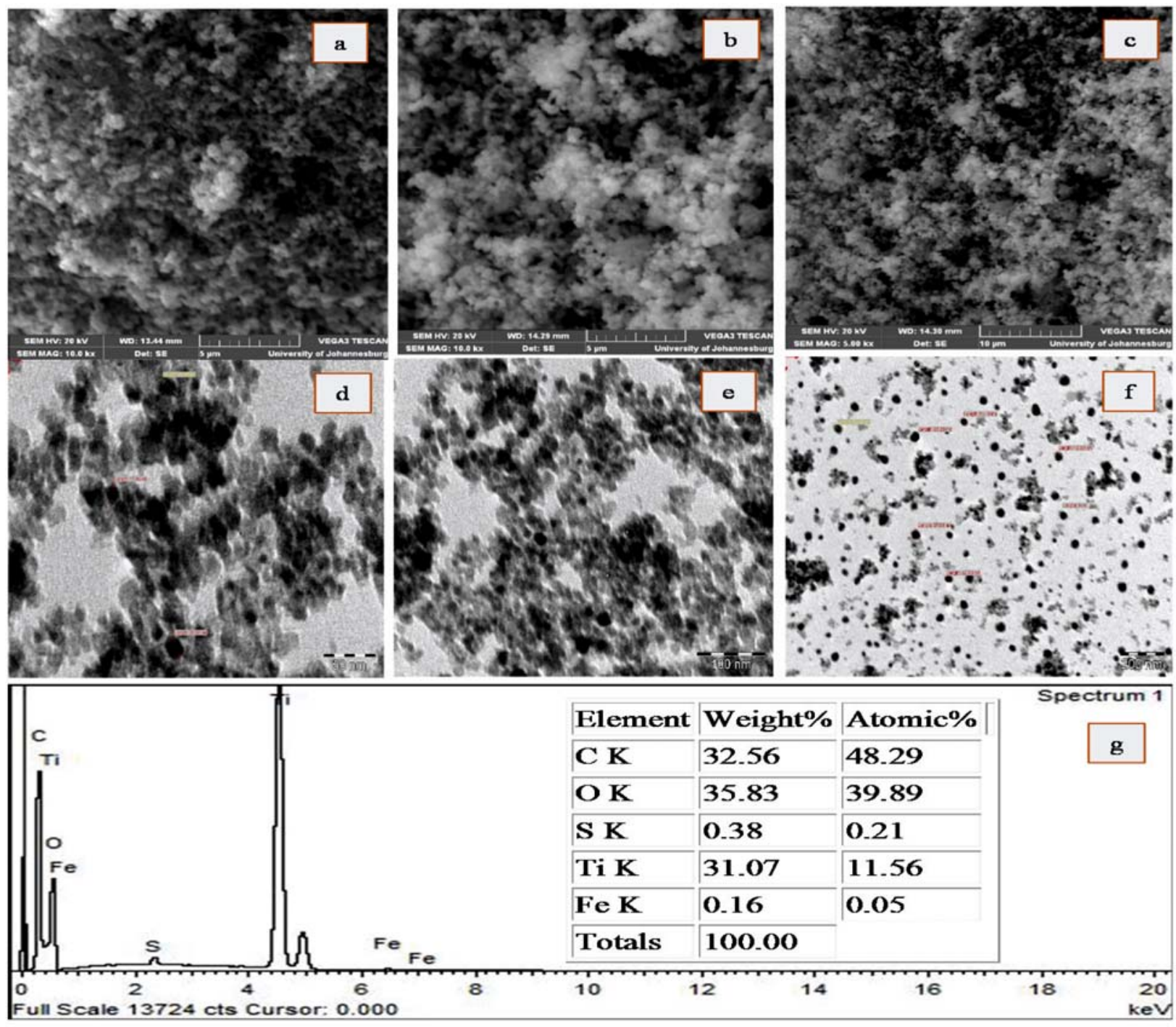

Figure 4 (a) $\mathrm{SEM}$ image $\mathrm{TiO}_{2}$ (b) $\mathrm{SEM}$ image $\mathrm{C} / \mathrm{S}-\mathrm{TiO}_{2}$ (c) $\mathrm{SEM}$ image of $\mathrm{Fe}^{3+} / \mathrm{C} / \mathrm{S}$-doped $\mathrm{TiO}_{2}\left(1.0 \% \mathrm{Fe}^{3+}\right.$ ) (d) $\mathrm{TEM}$ image of TiO ${ }_{2}$ (e) TEM image of $\mathrm{C} / \mathrm{S}-\mathrm{TiO}_{2}$ (f) TEM image of $\mathrm{Fe}^{3+} / \mathrm{C} / \mathrm{S}$-doped $\mathrm{TiO}_{2}\left(1.0 \% \mathrm{Fe}^{3+}\right)$ and (g) EDX spectrum of $\mathrm{Fe}^{3+} / \mathrm{C} / \mathrm{S}$-doped $\mathrm{TiO}_{2}\left(1.0 \% \mathrm{Fe}^{3+}\right)$ 
persive X-ray (EDX) respectively. The SEM images of Ti$\mathrm{O}_{2}, \mathrm{C} / \mathrm{S}-\mathrm{TiO}_{2}, \mathrm{Fe}^{3+} / \mathrm{C} / \mathrm{S}$-doped $\mathrm{TiO}_{2}\left(1.0 \% \mathrm{Fe}^{3+}\right)$ (Figure $4 \mathrm{a}, 4 \mathrm{~b}$ and $4 \mathrm{c})$ respectively, and the TEM images of $\mathrm{TiO}_{2}$, $\mathrm{C} / \mathrm{S}-\mathrm{TiO}_{2}$ and $\mathrm{Fe}^{3+} / \mathrm{C} / \mathrm{S}-\mathrm{TiO}_{2}\left(1.0 \% \mathrm{Fe}^{3+}\right.$ ) (Figure $4 \mathrm{~d}, 4 \mathrm{e}$ and 4f) respectively revealed the crystalline and small-sized nature of the catalysts with distinct boundaries. Some aggregation of the nanoparticles was however observed. The EDX spectrum of $\mathrm{Fe}^{3+} / \mathrm{C} / \mathrm{S}$-doped $\mathrm{TiO}_{2}\left(1.0 \% \mathrm{Fe}^{3+}\right)$ nanoparticle is shown in (Figure 4g). The EDX spectrum confirmed $\mathrm{Ti}, \mathrm{O}, \mathrm{Fe}, \mathrm{C}$ and $\mathrm{S}$ as the components of the synthesized catalyst. The result shows strong peaks for $\mathrm{Ti}, \mathrm{O}$, and $\mathrm{C}$.

\section{5. UV-Vis Analysis}

The UV-Vis absorption spectra of pure $\mathrm{TiO}_{2}$, $\mathrm{C} / \mathrm{S}-\mathrm{TiO}_{2}$ and $\mathrm{Fe}^{3+} / \mathrm{C} / \mathrm{S}-\mathrm{TiO}_{2}$ with varying wt $\%$ of $\mathrm{Fe}^{3+}$ is displayed in Figure 5. A significant red shift in the absorption spectrum of the pure $\mathrm{TiO}_{2}$ with the introduction of $\mathrm{Fe}$, $\mathrm{C}$ and $\mathrm{S}$ can be observed. The absorption edge of the pure $\mathrm{TiO}_{2}$ occurred below $400 \mathrm{~nm}$, meaning that its light absorption is limited only to the UV light range. However, the absorption edge significantly shifted to around $500 \mathrm{~nm}$ with the addition of the dopants. This is an indication that doping of pure $\mathrm{TiO}_{2}$ with $\mathrm{C}, \mathrm{S}$, and $\mathrm{Fe}$ improved its visible light absorption ability. This occurrence can be explained in terms of quantum confinement effect. It is observable that $\mathrm{Fe}^{3+} / \mathrm{C} / \mathrm{S}-\mathrm{TiO}_{2}\left(0.3 \% \mathrm{Fe}^{3+}\right)$, (Figure $5 \mathrm{c}$ ) showed the highest absorption in the visible light region. The characteristic absorption band around $300 \mathrm{~nm}$ is a phenome-

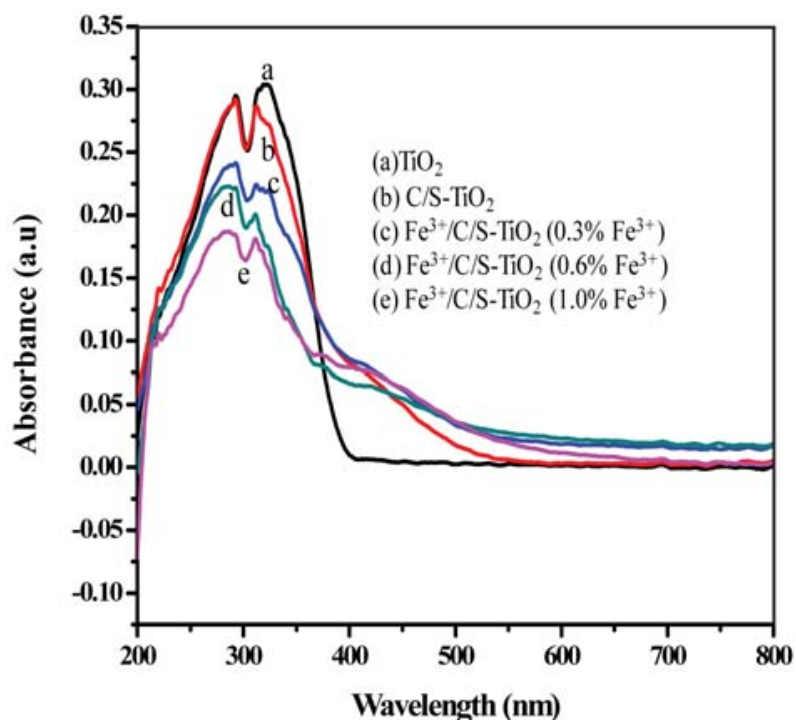

Figure 5. UV-Vis spectra of $\mathrm{TiO}_{2}, \mathrm{C} / \mathrm{S}$-doped $\mathrm{TiO}_{2}$ and $\mathrm{Fe}^{3+} / \mathrm{C} / \mathrm{S}-$ doped $\mathrm{TiO}_{2}$ with varying concentrations of $\mathrm{Fe}^{3+}$.

non attributed to inter band (valence and conduction band) and excitonic transition. ${ }^{27}$

\section{6. Band Gap Analysis}

The band gap values of the photocatalysts were obtained from a plot of Kubelka-Munk function through the
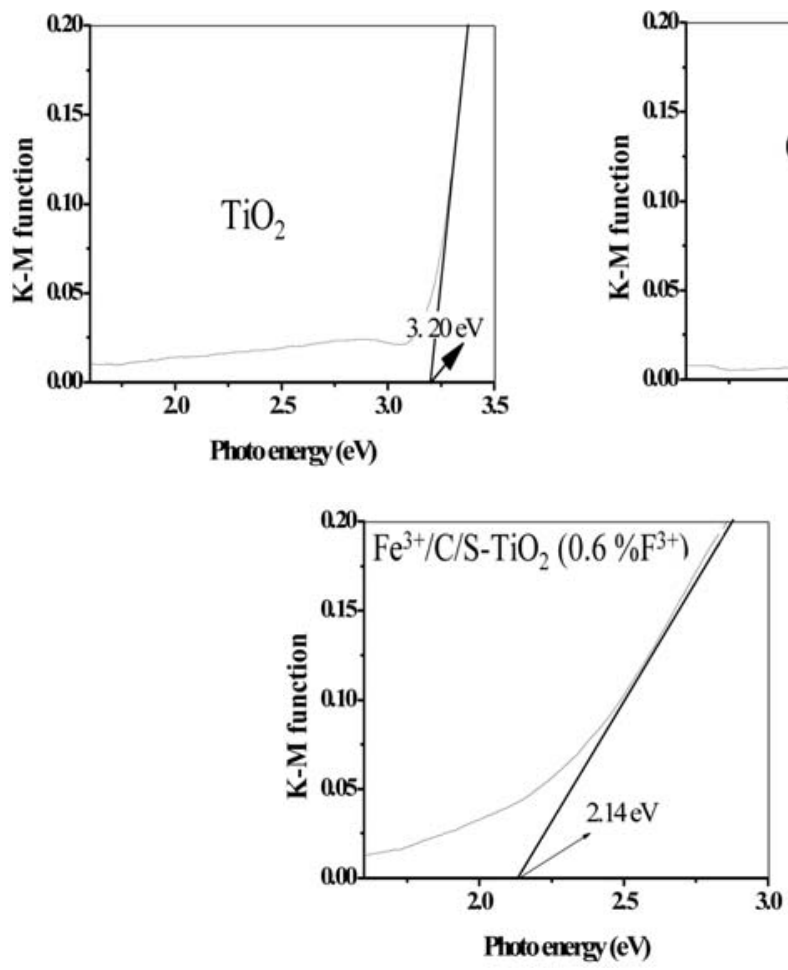
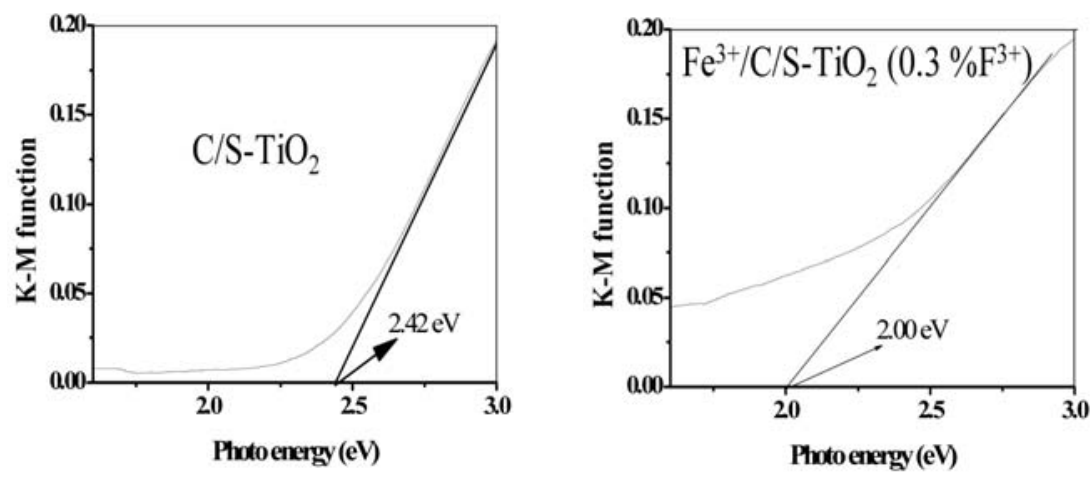

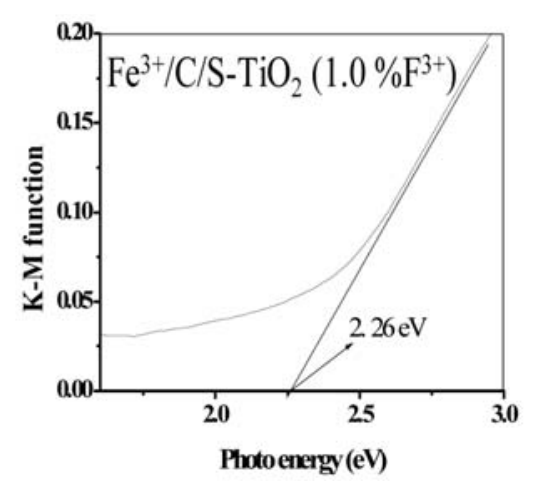

Figure 6 Tauc plot for pure $\mathrm{TiO}_{2}, \mathrm{C} / \mathrm{S}$-doped $\mathrm{TiO}_{2}$ and $\mathrm{Fe}^{3+} / \mathrm{C} / \mathrm{S}$-doped $\mathrm{TiO}_{2}$ with varying concentrations of $\mathrm{Fe}^{3+}$. 
use of reflectance data. The Kubelka-Munk function is given in equation 4 below:

$$
F(R)=\frac{(1-R)}{2 R}
$$

where, the reflectance $(\mathrm{R})=\mathrm{R}_{\text {sample }} / \mathrm{R}_{\text {reference }}$. The Tauc plots for the pure and modified $\mathrm{TiO}_{2}$ which were obtained by plotting Tauc function $\left(\breve{S}\left(\mathrm{~F}(\mathrm{R}) *{ }^{2}\right.\right.$ hí $^{\mathrm{n}}$ against photo energy (hí) with $\mathrm{n}=2$, are depicted in Figure 6 . The band gap values of the various catalysts are presented in Table 1. According to the results, the $\mathrm{Fe}^{3+} / \mathrm{C} / \mathrm{S}-\mathrm{TiO}_{2}\left(0.3 \% \mathrm{Fe}^{3+}\right)$ has the smallest band gap value of $2.00 \mathrm{eV}$ while pure Ti$\mathrm{O}_{2}$ has the highest value of $3.20 \mathrm{eV}$. This observation clearly verifies that doping of $\mathrm{TiO}_{2}$ with $\mathrm{Fe} / \mathrm{C}$ and $\mathrm{S}$ successfully reduced its band gap. The band gap values decrease in the following order: $\mathrm{Fe}^{3+} / \mathrm{C} / \mathrm{S}-\mathrm{TiO}_{2}\left(0.3 \% \mathrm{Fe}^{3+}\right)$ $<\mathrm{Fe}^{3+} / \mathrm{C} / \mathrm{S}-\mathrm{TiO}_{2}\left(0.6 \% \mathrm{Fe}^{3+}\right)<\mathrm{Fe}^{3+} / \mathrm{C} / \mathrm{S}-\mathrm{TiO}_{2}(1.0 \%$ $\left.\mathrm{Fe}^{3+}\right)<\mathrm{C} / \mathrm{S}-\mathrm{TiO}_{2}<\mathrm{TiO}_{2}$. Band gap narrowing can allow more absorption of visible light, and narrower band gap leads to more visible light absorption. ${ }^{32,33}$ It is however important to note that after the $0.3 \% \mathrm{Fe}^{3+}$ dopant concentration the band gap values increase consistently with an increase in $\mathrm{Fe}^{3+}$ concentration. Such observation has been attributed to the steady movement of the conduction band of $\mathrm{TiO}_{2}$ above the first excited state of the dopant ion due to the increased dopant concentration. The dopant ions at the first excited state interact with the conduction band electrons of $\mathrm{TiO}_{2}$ causing higher energy transfer from the $\mathrm{TiO}_{2}$ to the metal dopant ions ${ }^{34}$ In addition, increase in band gap value with increased dopant concentration could be ascribed to increase in n-type carrier concentration as the absorption edge shifts to higher energy level. ${ }^{35}$

\section{7. Photodegradation Analysis}

According to Harikumar et al. ${ }^{36}$ it is necessary to understand the reaction rate and the manner in which the rate is affected by different factors in in order to design an optimized photodegradation system. Photocatalytic degradation process depends on many factors such as such as $\mathrm{pH}$, light intensity, type of catalyst, oxygen concentration, concentration of the pollutant and the presence of inorganic ions. In this study, the degradation efficiencies of the dyes were studied based on catalyst type (effect of doping), light intensity and $\mathrm{pH}$.

\section{7. 1. Effect of Doping}

The photodegradation ability of the as-synthesized photocatalysts $\left(\mathrm{TiO}_{2}, \mathrm{C} / \mathrm{S}-\mathrm{TiO}_{2}, \mathrm{Fe}^{3+} / \mathrm{C} / \mathrm{S}-\mathrm{TiO}_{2}(0.3 \%\right.$ $\left.\mathrm{Fe}^{3+}\right), \mathrm{Fe}^{3+} / \mathrm{C} / \mathrm{S}-\mathrm{TiO}_{2}\left(0.6 \% \mathrm{Fe}^{3+}\right)$ and $\mathrm{Fe}^{3+} / \mathrm{C} / \mathrm{S}-\mathrm{TiO}_{2}$ $\left(1.0 \% \mathrm{Fe}^{3+}\right)$ was tested by applying them in the degradation of $20 \mathrm{~mL}(20 \mathrm{ppm})$ solution of methyl orange (monoazo dye) and congo red (diazo dye) with $0.02 \mathrm{~g}$ of each catalyst. This experiment was carried out under simulated visible light intensity of $1 \mathrm{sun}$ for $180 \mathrm{~min}$. In addition, the degradation experiment was performed using bare $\mathrm{TiO}_{2}$ in the absence of UV filter. This was intended to find out the influence of UV filter on photocatalytic performance of $\mathrm{TiO}_{2}$. Bank experiment (without catalyst) was also performed. The result for methyl orange degradation is shown in Figure 7 (A) while that of congo red is presented in Figure 7 (B). It is apparent that the photodegradation efficiency of all the catalysts against both methyl orange and congo red exhibited the same trend where $\mathrm{Fe}^{3+} / \mathrm{C} / \mathrm{S}-\mathrm{TiO}_{2}$ $\left(0.3 \% \mathrm{Fe}^{3+}\right)$ exhibited the best degradation efficiency against both dyes while $\mathrm{TiO}_{2}$ displayed the least degradation efficiency for both dyes. The rest of the catalysts degraded both dyes in the following order: $\mathrm{C} / \mathrm{S}-\mathrm{TiO}_{2}<$ $\mathrm{Fe}^{3+} / \mathrm{C} / \mathrm{S}-\mathrm{TiO}_{2}\left(1.0 \% \mathrm{Fe}^{3+}\right)<\mathrm{Fe}^{3+} / \mathrm{C} / \mathrm{S}-\mathrm{TiO}_{2}\left(0.6 \% \mathrm{Fe}^{3+}\right)$. Compared to the use of UV filter, the bare $\mathrm{TiO}_{2}$ demonstrated higher photocatalytic degradation efficiency against both dyes in the absence of UV filter. This means that, though not to an appreciable extent, the unmodified $\mathrm{TiO}_{2}$ is relatively efficient in the UV range compared to the visible light range. However, the presence of the dopants extent it's activity to the visible light range, resulting in higher degradation efficiency of the modified $\mathrm{TiO}_{2}$ samples. The bank test indicated that photolysis of both dyes was very slow. The percentage degradation of both dyes by each catalyst is presented in Table 1 . The enhanced photocatalytic activity of $\mathrm{Fe}^{3+} / \mathrm{C} / \mathrm{S}-\mathrm{TiO}_{2}\left(0.3 \% \mathrm{Fe}^{3+}\right)$ compared to other catalysts can be attributed to its improved visible light absorption (Figure 5), larger surface area, and reduced bad gap (Table 1). These factors possibly resulted in improved utilization of visible light instead of UV light, charge carrier transfer efficiency, enhanced adsorption of dye molecules and subsequent photodegradation due to large surface area and retardation of electronhole recombination emanating from acceptance of electrons from the conduction band by the dopant ions.

It is obvious, by comparing Figure 7 (A and B); that the monoazo dye was degraded faster than the diazo dye. All the catalysts demonstrated higher photodegradation of the monoazo dye compared to the diazo dye. For example, the best photocatalyst, $\mathrm{Fe}^{3+} / \mathrm{C} / \mathrm{S}-\mathrm{TiO}_{2}\left(0.3 \% \mathrm{Fe}^{3+}\right)$, degraded about $93 \%$ of methyl orange within 180 min (Figure $7 \mathrm{~A}$ ) while about $87 \%$ of congo red was degraded by the same catalyst within the same time frame (Figure 7B). This difference in photodegradation efficiency of the two azo dyes can be ascribed to structural differences. According to Figure 1, methyl orange contains one azo bond and one sulphonic group while congo red contain two azo bonds and two sulphonic groups. Meanwhile, the degradation of azo dyes is initiated by the electrophilic cleavage of its chromophoric azo bond $(-\mathrm{N}=\mathrm{N}-)$ attached to the naphthalene ring. ${ }^{37}$ Thus the more azo bonds there are in the structure of the dye the longer time it will take to degrade the dye. In addition, azo dyes colour removal and degradation rates have been observed to be proportional to the number of azo and sulphonic groups present in their 
molecules. ${ }^{9}$ It can therefore be proposed that there exist a direct relationship between the dyes degradation efficiency and the number of azo bonds and sulphonic groups available in the dye molecules.

a)

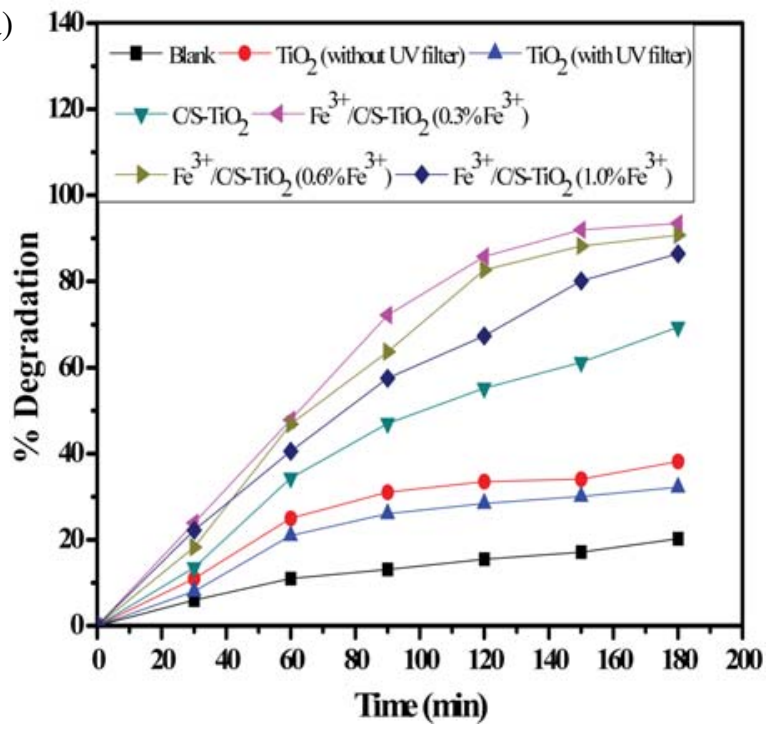

b)

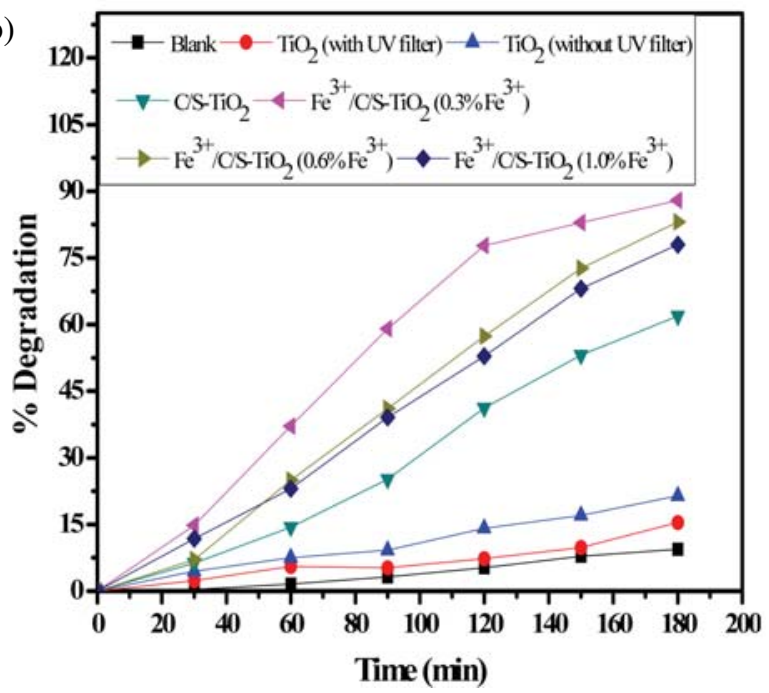

Figure 7. Effect of catalyst doping on degradation efficiency of (A) methyl orange and (B) Congo red by $\mathrm{TiO}_{2}, \mathrm{C} / \mathrm{S}$-doped $\mathrm{TiO}_{2}$ and $\mathrm{Fe}^{3+} / \mathrm{C} / \mathrm{S}$-doped $\mathrm{TiO}_{2}$ with varying concentrations of $\mathrm{Fe}^{3+}$.

In order to confirm the proposition that degradation efficiencies of the dyes were influenced by the azo bonds and sulphonic groups present in their molecules, photocatalytic degradation of a $20 \mathrm{~mL}(20 \mathrm{ppm})$ triazo dye (Direct blue 71) was further performed using $0.02 \mathrm{~g}$ of $\mathrm{Fe}^{3+} / \mathrm{C} / \mathrm{S}-\mathrm{TiO}_{2}\left(0.3 \% \mathrm{Fe}^{3+}\right)$ for $180 \mathrm{~min}$. This compound has three azo bonds and four sulphonic groups. The result (Figure 8) show that the dye experienced 62.8\% degradation efficiency. Compared to the degradation efficiencies of methyl orange (93.5\%) and Congo red (87.9\%), direct blue 71 was degraded at a comparatively lower rate. This observation confirms the proposed direct relationship between the dyes degradation efficiency and the number of azo bonds and sulphonic groups available in dye molecules.

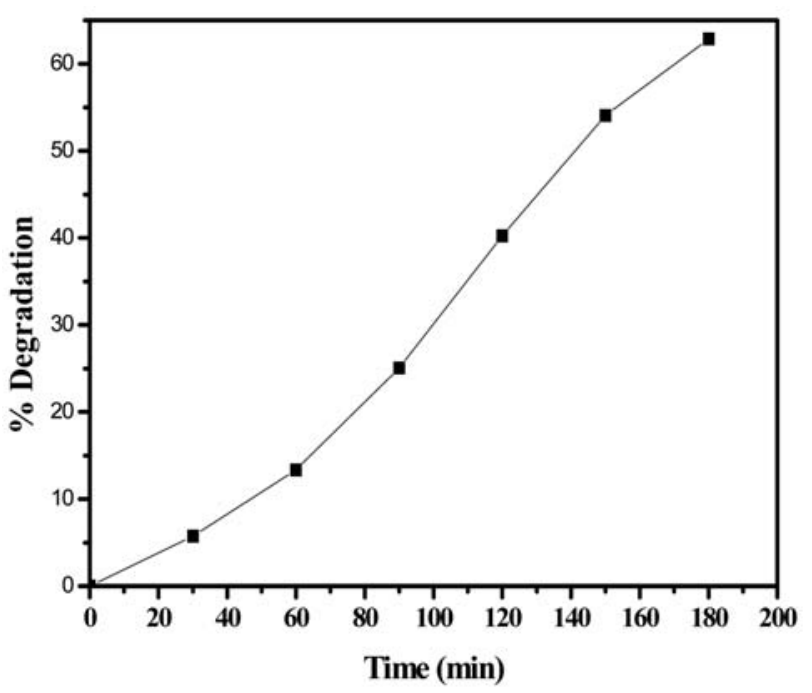

Figure 8. Degradation efficiency of direct blue 71 by of $\mathrm{Fe}^{3+} / \mathrm{C} / \mathrm{S}-\mathrm{TiO}_{2}\left(0.3 \% \mathrm{Fe}^{3+}\right.$

Pseudo-first-order kinetics (Eqn 5) was used to determine the rate of degradation of the dyes by the various catalysts.

$$
\operatorname{In} \frac{C o}{C t}=\mathrm{k}(\mathrm{t})
$$

where $\mathrm{C}_{\mathrm{o}}$ is the initial concentration, $\mathrm{C}_{\mathrm{t}}$ is the time $\mathrm{t}$ and $\mathrm{k}$ is the rate constant.

The results are presented in Figure 9 (A and B) for methyl orange and Congo red degradation rates respectively. The result show that the two dyes were degraded at different rates by all the catalysts. $\mathrm{Fe}^{3+} / \mathrm{C} / \mathrm{S}-\mathrm{TiO}_{2}(0.3 \%$ $\mathrm{Fe}^{3+}$ (the best photocatalyst) degraded both methyl orange and Congo red at faster rates of $16.28 \times 10^{-3}$ and $15.33 \times$ $10^{-3}$ while the bare $\mathrm{TiO}_{2}$ degraded both dyes at the lowest rates of $2.66 \times 10^{-3}$ and $1.80 \times 10^{-3}$ respectively. Comparatively, methyl orange experienced faster rate of degradation than Congo red.

Because of its higher photocatalytic degradation efficiency against the two azo dyes, $\mathrm{Fe}^{3+} / \mathrm{C} / \mathrm{S}-\mathrm{TiO}_{2}(0.3 \%$ $\mathrm{Fe}^{3+}$ ) was the catalyst used to study the effects of light intensity and $\mathrm{pH}$ on the degradation efficiency of azo dyes. In addition, because methyl orange was degraded faster, it was chosen as a representative azo dye to study the effect of light intensity and $\mathrm{pH}$ on photodegradation of azo dyes. 

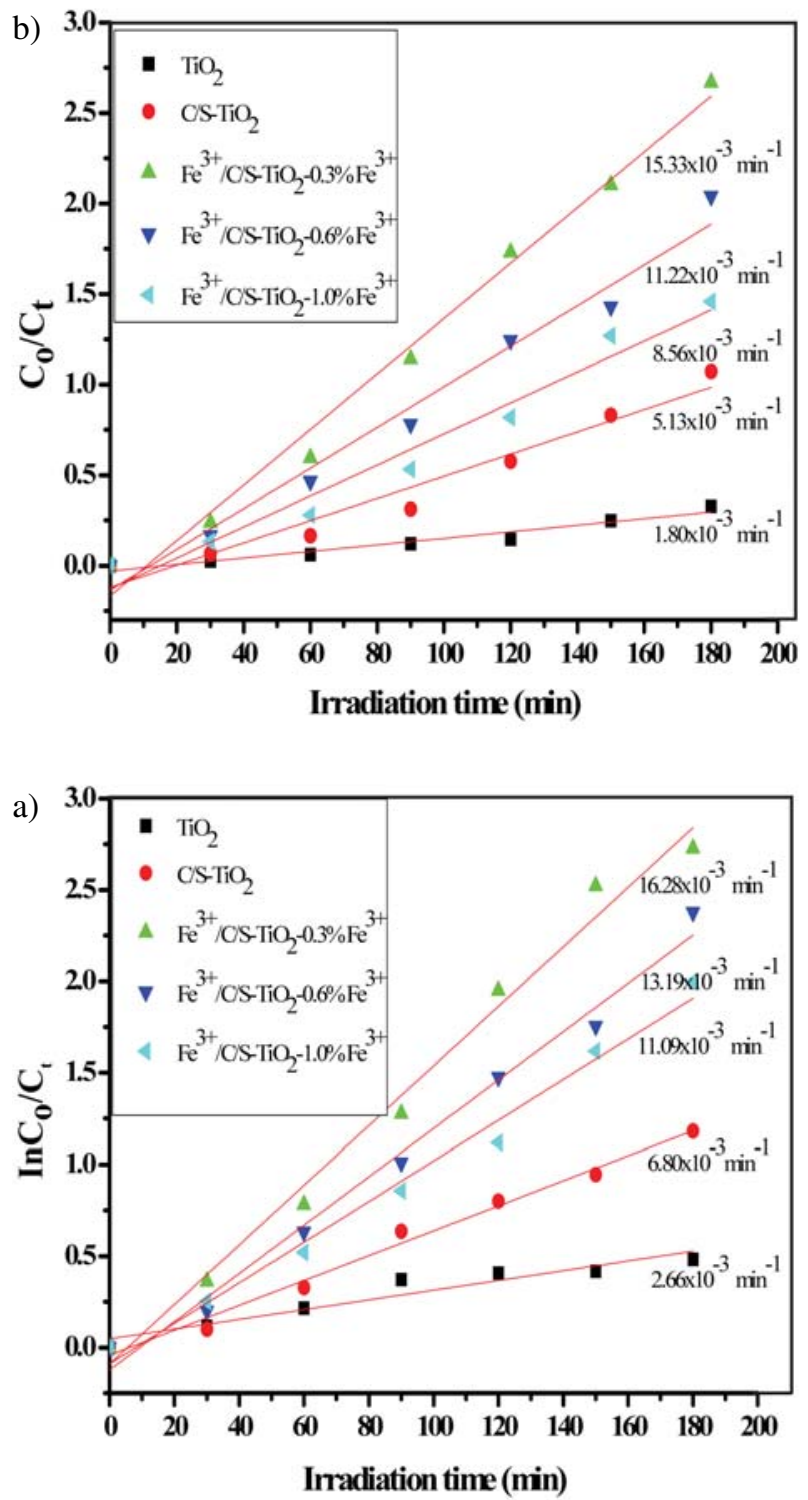

Figure 9. Kinetics of (A) methyl orange degradation and (B) Congo red degradation by $\mathrm{TiO}_{2}, \mathrm{C} / \mathrm{S}$-doped $\mathrm{TiO}_{2}$ and $\mathrm{Fe}^{3+} / \mathrm{C} / \mathrm{S}$ doped $\mathrm{TiO}_{2}$ with varying concentrations of $\mathrm{Fe}^{3+}$ under visible light irradiation.

\section{7. 2. Effect of $\mathbf{p H}$}

One of the major factors that affect the degradation of pollutants by semiconductor photocatalyst is the solution $\mathrm{pH}$ since the catalyst surface charge and isoelectric point depend on $\mathrm{pH}$. In addition, the solution $\mathrm{pH}$ is also a factor that determines the charge on the dye molecule. The study of the effect of $\mathrm{pH}$ on the photocatalytic degradation of organic pollutant is therefore an important consideration. In this study, the effect of $\mathrm{pH}$ on azo dye degradation was performed in the range of 2 to 12 with $0.02 \mathrm{~g}$ of $\mathrm{Fe}^{3+} / \mathrm{C} / \mathrm{S}-\mathrm{TiO}_{2}\left(0.3 \% \mathrm{Fe}^{3+}\right)$ photocatalyst dispersed in 20 $\mathrm{mL}(20 \mathrm{ppm})$ solution of methyl orange. The results are displayed in Figure 10. The result showed that the photo- degradation efficiency of methyl orange decreased consistently with increasing $\mathrm{pH}$ from $\mathrm{pH} 2$ to 12 . There are many factors that determine the effect of $\mathrm{pH}$ on dye photocatalytic degradation process, amongst which is the acid-base property of the photocatalyst which can be explained in terms of zero point charge, ${ }^{38}$ and the fact that the ionization state of the dye molecule depends on the solution $\mathrm{pH}$. $\mathrm{TiO}_{2}$ has a zero point charge $(\mathrm{pH}$ pzc) at $\mathrm{pH}$ 6.8. This means that at $\mathrm{pH}<6.8$ (acidic medium) the surface of $\mathrm{TiO}_{2}$ becomes positively charged, and negatively charged in alkaline medium $(\mathrm{pH}>6.8) .{ }^{36,39}$ On the other hand, due to its sulfonic group $\left(\mathrm{SO}_{3}^{-}\right)$, methyl organge is negatively charged in solution. Hence there exist electrostatic force of attraction between the positively charged $\mathrm{TiO}_{2}$ surface and the negatively charged sulfonic groups of methyl orange in acidic medium. Consequently, the dye molecules were strongly adsorbed onto the $\mathrm{TiO}_{2}$ surface resulting in efficient degradation of the dye in acidic medium. In the alkaline medium however, both the $\mathrm{TiO}_{2}$ surface and the dye molecules are negatively charged resulting in electrostatic repulsion of the dye molecules. This caused the dye molecules to be sparingly adsorbed on the $\mathrm{TiO}_{2}$ surface resulting in diminished degradation efficiency of the dye in alkaline medium. The result therefore indicates that the degradation efficiency of the dye depends on the amount of dye molecule adsorbed onto the $\mathrm{TiO}_{2}$ surface.

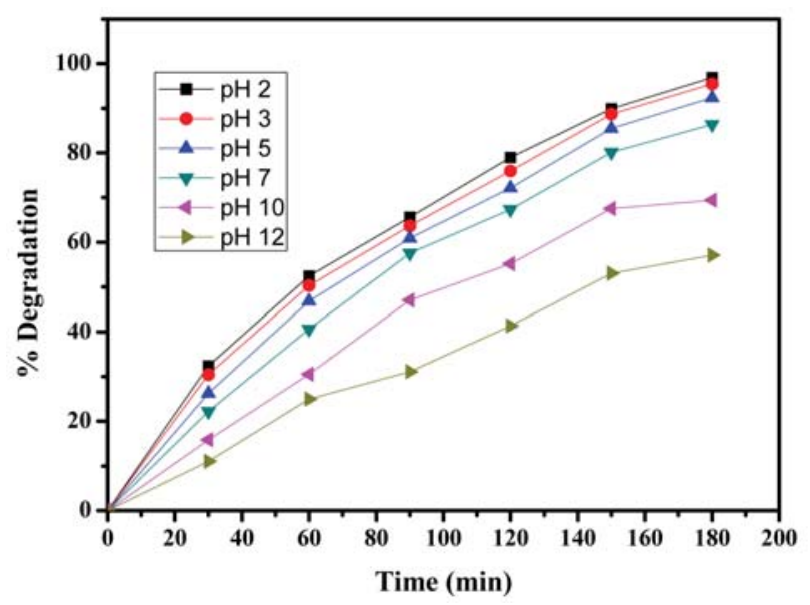

Figure 10. Effect of $\mathrm{pH}$ on degradation efficiency of methyl orange by $\mathrm{Fe}^{3+} / \mathrm{C} / \mathrm{S}$-doped $\mathrm{TiO}_{2}\left(0.3 \% \mathrm{Fe}^{3+}\right)$ nanoparticle.

\section{7. 3. Effect of Light Intensity}

Photodegradation of methyl orange solutions under varied visible light intensities, 0.5 sun, 0.7 sun, 1.0 sun and 1.3 sun intensities, was performed to determine the influence of light intensity on the degradation efficiencies of the dye. Oriel PV reference cell system, model $91150 \mathrm{~V}$, was used to measure the irradiance of the simulated sun. This experiment was performed with the same catalyst 
and dye solution specifications of $0.02 \mathrm{~g}$ catalyst suspended in $20 \mathrm{~mL}(20 \mathrm{ppm})$ solutions within an irradiation time of $180 \mathrm{~min}$. Figure 11 represents the outcome of this analysis. There was a direct relationship between visible light intensity and degradation efficiency of the dye with respect to 0.5 sun, 0.7 sun and 1.0 sun. There was minimal degradation of the dye at 0.5 sun and 0.7 sun intensity while higher degradation was observed at 1.0 sun intensity to the point that about $93 \%$ of the dye was degraded within $120 \mathrm{~min}$. Meanwhile, about $36 \%$ and $55 \%$ of the dye were degraded within the same $120 \mathrm{~min}$ at 0.5 sun and 0.7 sun intensities respectively. This occurrence may be related to the increase in light intensity resulting in an increase of the number of photons that reach the surface of the catalyst. As a result, the number of exited catalyst molecules increase causing an increase in the number of hy-

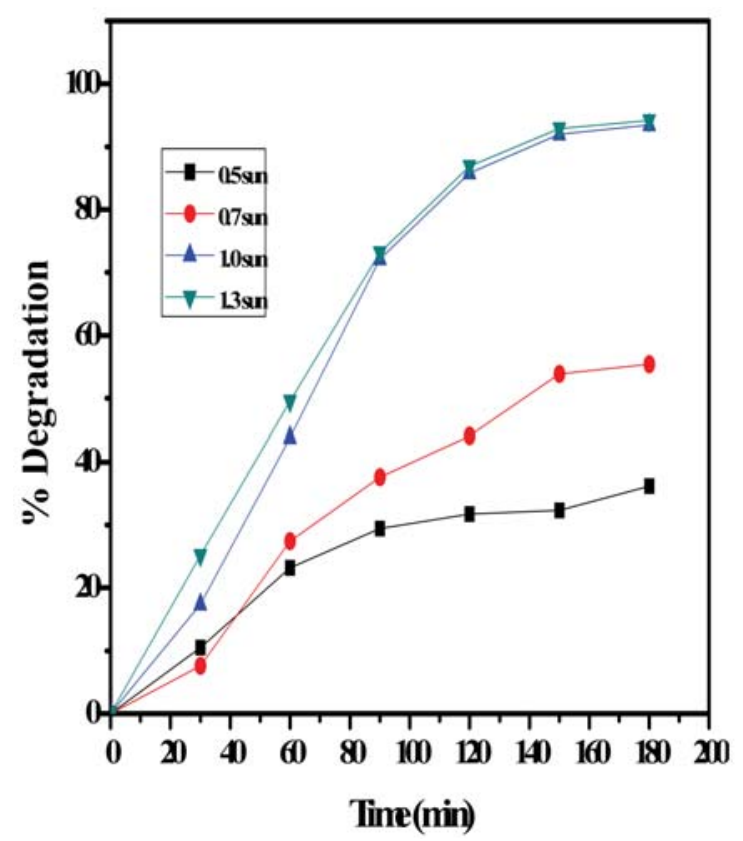

Figure 11. Effect of light intensity on degradation efficiency of methyl orange by $\mathrm{Fe}^{3+} / \mathrm{C} / \mathrm{S}$-doped $\mathrm{TiO}_{2}\left(0.3 \% \mathrm{Fe}^{3+}\right)$ nanoparticle.

droxyl and superoxide radicals responsible for the photodegradation process. On the other hand, an increase in light intensity to 1.3 sun did not result in any significant corresponding increase in the degradation efficiency. This probably means that the optimum number of photons required for an effective photocatalytic degradation was attained at 1.0 sun. Therefore, an increase in photon number at 1.3 sun did not produce any major change in the degradation efficiency.

\section{7. 4. Total Organic Carbon Analysis}

Total organic carbon (TOC) analysis was performed in order to determine the extent of mineralization of the methyl orange attained during the photodegradation process. This analysis is necessary because the disappearance of dye colour alone cannot be used as a measure to determine complete mineralization of the dye. Furthermore, the photodegradation process can result in the formation of colourless dye intermediates resulting in the disappearance of colour but may actually be more toxic than the dye itself. The analysis was done on the sample irradiated with 1 sun intensity with $\mathrm{Fe}^{3+} / \mathrm{C} / \mathrm{S}-\mathrm{TiO}_{2}\left(0.3 \% \mathrm{Fe}^{3+}\right)$ nanoparticle. The result of this analysis (Figure 12) revealed that the colour disappearance of the dye was faster than the degree of mineralization. The highest TOC removal was around $65 \%$. The quick disappearance of colour could arise from the cleavage of the azo bond while the high TOC value may be due to difficulty in converting the $\mathrm{N}$ atom of the dye into oxidized nitrogen compounds since the hydroxyl radicals are short-lived and aliphatic chain interaction with hydroxyl radicals is minimal. ${ }^{40}$ This could mean that the dye molecules were converted to other intermediate forms which still exist in the solution irrespective of the dye decolourization, and signifies that degradation of the dye beyond 180 min may lead to complete mineralization.

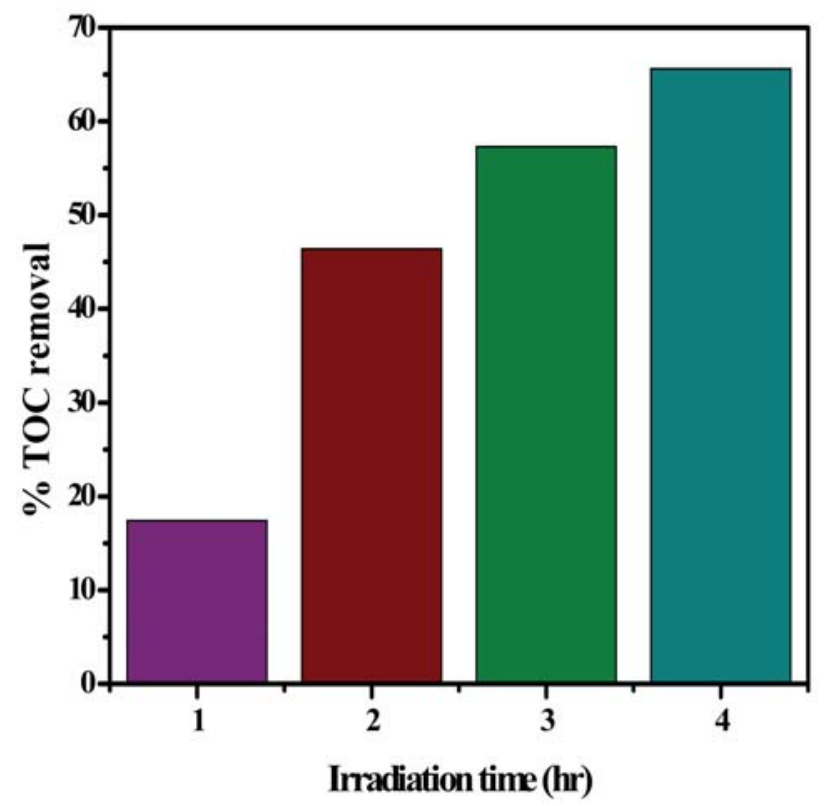

Figure 12. Percent TOC removal by $\mathrm{Fe}^{3+} / \mathrm{C} / \mathrm{S}-\mathrm{TiO}_{2}\left(0.3 \% \mathrm{Fe}^{3+}\right)$ nanoparticle.

\section{Conclusion}

The visible light active hetero-elements doped $\mathrm{TiO}_{2}$ was successfully synthesized through sol-gel method, confirmed by FTIR, XRD, EDX AND UV-Vis analyses. $\mathrm{Fe}^{3+} / \mathrm{C} / \mathrm{S}-\mathrm{TiO}_{2}\left(0.3 \% \mathrm{Fe}^{3+}\right)$ was observed to be the best photocatalyst for the degradation of the azo dyes. The enhanced photocatalytic activity of $\mathrm{Fe}^{3+} / \mathrm{C} / \mathrm{S}-\mathrm{TiO}_{2}(0.3 \%$ 
$\mathrm{Fe}^{3+}$ ) compared to other catalysts can be attributed to its improved visible light absorption, larger surface area, and reduced bad gap. These factors possibly resulted in improved utilization of visible light, enhanced charge carrier transfer efficiency, greater adsorption of dye molecules and subsequent effective photodegradation of the dye. The monoazo dye experienced higher degradation efficiency over the diazo dye. The fast photodegradation of the monoazo dye compared to the diazo dye indicates that the number of azo bonds and sulphonic groups present in the azo dyes determined their photodegradation rate. The result of $\mathrm{pH}$ analysis showed that the photodegradation efficiency of methyl orange decreased consistently with increasing $\mathrm{pH}$ from 2 to 12 indicating that the degradation efficiency of the dye depend on the amount of dye molecule adsorbed on the $\mathrm{TiO}_{2}$ surface. There was a direct relationship between visible light intensity and degradation efficiency of the dye. TOC analysis revealed incomplete mineralization of the dye molecules within 180 min irrespective of the dye decolourization thus signifying that degradation of the dye beyond 180 min may lead to complete mineralization.

\section{Reference}

1. B. Manu, S. Chaudhari, Bioresour. Technol. 2002, 82, 225231. http://dx.doi.org/10.1016/S0960-8524(01)00190-0

2. N. D. Lourenço, J. M. Novais, H. M. Pinheiro, Environ technol. 2003, 24, 679-686.

http://dx.doi.org/10.1080/09593330309385603

3. H. Zollinger. Color chemistry - Synthesis, properties, and applications of organic dyes and pigments, Willey-VCH: New York, 2003, pp. 219-243.

4. M. C. Costa, F. S. B. Mota, A. B. D. Santos, G. L. F. Mendonça, R. F. D. Nascimento, Quím. Nova, 2012, 35, 482486.

http://dx.doi.org/10.1590/S0100-40422012000300008

5. Y. H. Lee, S. G. Pavlostathis, Water Res. 2004, 38, 18381852. http://dx.doi.org/10.1016/j.watres.2003.12.028

6. A. Giwa, P. O. Nkeonye, K. A. Bello, E. G. Kolawole, A. O. Campos, Int. J. App, 2012, 2.

7. S. Parra, J. Olivero, C. Pulgarin, Appl. Catal. Part B: Environ. 2002, 36, 75-85.

http://dx.doi.org/10.1016/S0926-3373(01)00283-1

8. S. Parra, J. Olivero, L. Pacheco, C. Pulgarin. Catal. Part B: Environ. 2003 43, 293-301.

9. S. A. Abo-Farha, J.Am. Sci, 2010, 6, 130-142.

10. U. G. Akpan, B. H. Hameed, J. Hazard. Mater, 2009,170, 520-529. http://dx.doi.org/10.1016/j.jhazmat.2009.05.039

11. X. Zhang, Y. Wang, G. Li, J Mol. Catal A-Chem. 2005, 237, 199-205. http://dx.doi.org/10.1016/j.molcata.2005.03.043

12. B. Tryba, Int. J. Photoenergy, 2008, 2008.

13. C. Adán, A. Bahamonde, M. Fernández-García, A. MartínezArias, Appl. Catal B: Environ. 2007, 72, 11-17. http://dx.doi.org/10.1016/j.apcatb.2006.09.018
14. A. K. Ghosh, H. P. Maruska, J. Electrochem. Soc. 1977, 124, 1516-1522. http://dx.doi.org/10.1149/1.2133104

15. W. Choi, A. Termin, M. R. Hoffmann, J. Phys. Chem, 1994, 98, 13669-13679. http://dx.doi.org/10.1021/j100102a038

16. N. Riaz, B. K. Mohamad Azmi, A. M. Shariff, Adv. Mat. Res. 2014, 925, 689-693. http://dx.doi.org/10.4028/www.scientific.net/AMR.925.689

17. R. Y. O. J. I. Asahi, T. A. K. E. S. H. I.Morikawa, T. Ohwaki, K. Aoki, Y. Taga, Science, 2001, 293, 269-271. http://dx.doi.org/10.1126/science.1061051

18. S. Sakthivel, H. Kisch, Angew. Chem. Int. Ed. 2003, 42, 4908-4911. http://dx.doi.org/10.1002/anie.200351577

19. T. Umebayashi, T. Yamaki, H. Itoh, K. Asai, Appl. Phys. Lett. 2002, 81, 454-456. http://dx.doi.org/10.1063/1.1493647

20. J. C. Yu, J. Yu, W. Ho, Z. Jiang, L. Zhang, Chem. Mater. 2002, 14, 3808-3816. http://dx.doi.org/10.1021/cm020027c

21. D. E. De Vos, M. Dams, B. F. Sels, P. A. Jacobs, Chem Rev, 2002, 102, 3615-3640. http://dx.doi.org/10.1021/cr010368u

22. E. Barborini, A. M. Conti, I. Kholmanov, P. Piseri, A. Podestà, P. Milani, M. Sancrotti, Adv. Mater, 2005, 17, 18421846. http://dx.doi.org/10.1002/adma.200401169

23. J. C. Yu, W. Ho, J. Yu, H. Yip, P. K. Wong, J. Zhao, Environ. Sci. Technol, 2005, 39, 1175-1179. http://dx.doi.org/10.1021/es035374h

24. V. Etacheri, M. K. Seery, S. J. Hinder, S. C. Pillai, Chem. Mater, 2010, 22, 3843-3853. http://dx.doi.org/10.1021/cm903260f

25. F. Wei, L. Ni, P. Cui, J. Hazard. Mater. 2008, 156, 135-140. http://dx.doi.org/10.1016/j.jhazmat.2007.12.018

26. B. Liang, L Andrews, J. Phys. Chem A, 2002, 106, 69456951. http://dx.doi.org/10.1021/jp025915+

27. L. Ren, X. Huang, F. Sun, X. He, Mater lett, 2007, 61, 427-431. http://dx.doi.org/10.1016/j.matlet.2006.04.097

28. J. Zhu, W. Zheng, B. He, J. Zhang, M. Anpo, J. Mol. Catal A: Chem. 2004, 216, 35-43. http://dx.doi.org/10.1016/j.molcata.2004.01.008

29. A. K. Singh, U. T. Nakate, Sci. World J. 2014, 2014.

30. J. Moon, H. Takagi, Y. Fujishiro, M. Awano, J. Mater. Sci. 2001, 36, 949-955. http://dx.doi.org/10.1023/A:1004819706292

31. J. Moon, H. Takagi, Y. Fujishiro, M. Awano, J. Mater. Sci, 2001, 36, 949-955. http://dx.doi.org/10.1023/A:1004819706292

32. M. Xing, X. Li, J. Zhang. Sci. Rep. 2014, 4, 1-7.

33. K. Maeda, K. Domen. J. Phys. Chem. Lett. 2010, 1, 26552661. http://dx.doi.org/10.1021/jz1007966

34. S. Kumar, Z. Jindal, N. Kumari, N. K. Verma. J Nanopart. Res. 2011, 13, 5465-5471. http://dx.doi.org/10.1007/s11051-011-0534-5

35. S. A. Yousaf, S. Ali. Coden. Jnsmac. 2008, 48, 43-50.

36. P. S. Harikumar, L. Joseph, A. Dhanya, J. Environ. Eng. Ecol. Sci. 2013, 2, 2. http://dx.doi.org/10.7243/2050-1323-2-2

37. M. Muruganandham, M. Swaminathan, Dyes Pigm. 2004, 62, 269-275.

http://dx.doi.org/10.1016/j.dyepig.2003.12.006 
38. H. R. Pouretedal, M. Hosseini, Acta Chim. Slov, 2010, 57, 415-423.

39. N. Wang, J. Li, L. Zhu, Y. Dong, H. Tang, H. J. Photochem. Photobiol A: Chem. 2008, 198, 282-287. http://dx.doi.org/10.1016/j.jphotochem.2008.03.021

40. I. K. Konstantinou, T. A. Albanis, Appl. Catal. B: Environ. 2004, 49, 1-14.

http://dx.doi.org/10.1016/j.apcatb.2003.11.010

\section{Povzetek}

Tekom raziskav smo preučevali fotokatalitičen razpad monoazo (metiloranž) in diazo (kongo rdeče) barvil v vodnih raztopinah nanokompozitov $\mathrm{Fe}^{3+} / \mathrm{C} / \mathrm{S}$ dopiranega $\mathrm{TiO}_{2}$. Nanokompozite smo sintetizirali s sol-gel metodo in karakterizirali z naslednjimi tehnikami: XRD, FTIR, SEM, TEM, EDX, BET in UV-Vis. Fotokatalitični razpad barvil smo spremljali pod simulirano vidno svetlobo, uporabili pa smo $\mathrm{TiO}_{2}, \mathrm{C} / \mathrm{S}$ dopiran $\mathrm{TiO}_{2}$ in $\mathrm{Fe}^{3+} / \mathrm{C} / \mathrm{S}$ dopiran $\mathrm{TiO}_{2}$ z različnimi koncentracijami ionov $\mathrm{Fe}^{3+}$. Preučevali smo vpliv katalizatorja, $\mathrm{pH}$-ja raztopine in intenzitete svetlobe. $\mathrm{V}$ primeru $\mathrm{Fe}^{3+} / \mathrm{C} / \mathrm{S}$ dopiranega $\mathrm{TiO}_{2}$ smo opazili zmanjšano vrednost energijske špranje (band gap) in izboljšano aktivnost vidne svetlobe. Glede na fotokatalitično učinkovitost lahko preučevane materiale zapišemo v naslednjem vrstnem redu: $\mathrm{TiO}_{2}<\mathrm{C} / \mathrm{S} / \mathrm{do}-$ piran $\mathrm{TiO}_{2}<\mathrm{Fe}^{3+} / \mathrm{C} / \mathrm{S}$ dopiran $\mathrm{TiO}_{2} . \mathrm{Fe}^{3+} / \mathrm{C} / \mathrm{S}$ dopiran $\mathrm{TiO}_{2}\left(0.3 \% \mathrm{Fe}^{3+}\right)$ je izkazoval najboljše fotokatalitične lastnosti. $\mathrm{V}$ primeru monoazo barvila smo opazili višjo stopnjo razpada kot $\mathrm{v}$ primeru diazu barvila. Razpad azo barvil se je zmanjšal s povečanjem $\mathrm{pH}$ vrednosti od 2 do 12 . Zvišanje intenzitete vidne svetlobe je povečalo učinkovitost razpada barvil pod vplivom svetlobe. Opazili smo, da se je barvilo hitreje razbarvalo, kot pa mineraliziralo. 